\title{
KNOWLEDGE AND PRACTICE OF STAFF NURSES RELATED tO HEALTH CARE WASTE MANAGEMENT
}

${ }^{1}$ Dalia Reda Ahmed Sobh, ${ }^{2}$ Samah Faisal Fakhry and ${ }^{3}$ Hind Abdullah Mohamed

${ }^{1}$ B.Sc. Nursing, Faculty of Nursing, Suez Canal University.

${ }^{2}$ Assist. Prof. of Nursing Administration, Faculty of Nursing, Ain Shams University.

${ }^{3}$ Lecturer of Nursing Administration, Faculty of Nursing, Port Said University.

\begin{abstract}
Background: The management of healthcare waste is great importance due to its potential environmental hazards and public health risks. The safe management of healthcare waste may be achieved by ensuring care in dealing with the healthcare waste. Hence it is the ethical responsibility of management of hospitals and health care providers especially staff nurses. Aim: The present study aimed to assess knowledge and practice of staff nurses related to health care waste management in El-Zohor hospital. A descriptive study was utilized .Subjects \& Method: sample of 110 nurses. Data were collected using a knowledge questionnaire sheet and an observation checklist for assessing the practice of the staff nurses. Result: The results revealed that the majority of nurses had satisfactory knowledge regarding health care waste management and had adequate practices in most areas of waste management. Conclusion: The findings pointed to a statistically significant correlation between nurses' knowledge and practice regarding healthcare waste management. Recommendation: A close monitoring, to ensure the application of safety regulations in waste handling continuously.
\end{abstract}

Keywords: Health care, Knowledge, Practice, Staff nurses, Waste management 


\section{INTRODUCTION}

Hospitals are institutions providing various healthcare services to the community. Their activities may include curative, rehabilitative, preventive, patient care services and also promotion of health education. It is the duty of hospitals and health care establishments to look after the public health; this may be directed, through patient care, or indirectly by ensuring a clean, healthy environment for their employees and the community (Patil \& Pokhrel, 2012).

Health care waste $(\mathrm{HCW})$ defined as all wastes generated by health care and health research facilities and associated laboratories (Onursal, 2011). HCW is any solid or liquid waste which may present a threat of infection to humans. It is generated from health care establishments such as hospitals (during the diagnosis, treatment or immunization of human being, blood banks, clinic, dental practices, laboratories as well as medical research facilities, veterinary hospitals and other forms of health care services) (Sreegiri \& Babu, 2009).

Hospital waste is a special category of waste, which is highly hazardous due to its infectious and/or toxic characteristics. Furthermore, in health care units the direct exposure of waste management workers and members of the public for this type of waste increases the hazard that emerges from their treatment. Despite the fact that current medical waste management practices differ from hospital to hospital, the problematic areas are approximately the same for all healthcare units and at all stages of management, including segregation, collection, packaging, storage, transport, treatment and disposal (Fluke, 2000).

The health care team member is considered the first line of defense to face the risks of health care waste. If this risk passed the first line of defense the results become disastrous. Therefore, the hospital administration will not be able to face the hazard of healthcare waste successfully without the cooperation of the health care team member's nurses, doctors and housekeepers. Where the segregation system of healthcare waste starts at the point of generations. So the health care team members must be fully aware of all the types and risks of medical waste and how to deal with it (Goddu, Duvvuri \& Bakki, 2007; Pasupathi, Sindhu, Ponnusha \& Ambika, 2011). 
There is a concept that the medical waste management limited to the existence of incinerators and different processing methods. But this concept is wrong; healthcare waste management depends on the fundamental basis and working to create a medical waste treatment. The risk of the medical waste is not limited to accumulation and poor-treatment only, but also related to the infection and the risk of these wastes may occur before the arrival of this waste incinerators and different treatment methods (Mohammed, 2009).

To make sure that health care waste is properly managed in the long term, it is important to supervise on a regular basis the practices of the staff. This should be performed by the healthcare waste management officer and/or members of a healthcare waste management committee within each health care facility depending on the size of the facility. Typically, members of such committee are usually the same as those in charge of nosocomial infections. Appropriate ongoing training and awareness sessions should be organized accordingly to keep practicing at the best standards possible (Aukour, 2008; Fasola et al., 2008).

\section{SIGNIFICANCE OF THE STUDY:}

In Egypt, the awareness regarding hospital waste management in terms of its segregation, collection, storage, transportation \& disposal is lacking. Different hospital departments have different types of wastes. However, the spread of infection is more likely to occur in large wards, like surgical \& obstetrics departments where patients may be exposed to contaminated surgical wounds. In addition to this department, the highly hazardous waste is also due to the incorrect treatment and disposal of HCW. The nurses are the ones who are responsible for handling the disposal of waste and therefore they are exposed directly to these hazards (Aukour, 2008; Fasola et al., 2008).

So the importance of proper waste management and the lack of sound management system in their workplace are more needed. Therefore, the current study will be carried to assess knowledge and practice regarding healthcare waste management among the staff nurses. 


\section{AIM OF THE STUDY:-}

Assess knowledge and practice of staff nurses related to health care waste management.

\section{Research question}

A descriptive research design was utilized.

To achieve the aim of this study the following research questions are formulated:

1. What is the level of staff nurses' knowledge and practice regarding health care waste management?

2. Is there a relationship between the nurses' knowledge and their practice related to waste management?

\section{SUBJECTS AND METHOD:-}

\section{Research Design:}

A descriptive correlation research design was used for this study.

\section{Study Setting}

The present study was conducted in El-Zohor hospital, which affiliated with the ministry of health at Port-Said city.

\section{Description of Study Setting (El-Zohor Hospital):}

This hospital is one of the ideal model hospital, where it is one among the five hospitals have been accredited at the level of the republic and the hospital has already been receiving the foundation level.

The total hospital capacity is 72 beds and 110 staff nurses. It consists of five floors as follows:

1. First Floor: Includes Emergency Department, Out-patient Clinics, Sterilization Department and Radiology Department.

2. Second Floor: Includes Managerial Offices, Medical director Office, Dental clinic, Family planning clinic and Laboratory.

3. Third Floor: Includes Intensive care unit, Cardiac care unit and Operation Theater.

4. Fourth Floor: Includes Male and Female Medical Department and Ultrasound Unit.

5. Fifth Floor: Includes Male and Female Surgical Department. 


\section{Study Subjects:}

The subject of this study included all staff nurses who were working in the study setting with a total number (110) nurses.

\section{Inclusion criterion:}

1. Agree to participate in the study.

2. They have at least one year of experience in their current job.

\section{TOOLS FOR DATA COLLECTION:}

Data for this study was collected by using two tools:

\section{FIRST TOOL Knowledge Questionnaire Sheet (Appendix I):}

This tool was used for the purpose of assessing nurses' knowledge about health care waste management. It is divided into two parts:

\section{- The First Part: (Personal and Job Characteristics Data Sheet):}

This part was developed by the researcher, and aimed at collecting data about demographic and job characteristics as the respondent's age, gender, educational qualifications, and years of experience, working units, marital status and attendance of related training courses.

\section{- The Second Part: (Knowledge Questionnaire Sheet):}

This part was developed by the researcher based on scientific literature (WHO, 2005; Rao, 2008; Hegde et al., 2009; Athy, 2009; Sreegiri \& Babu, 2009; Soliman\&Ahmed 2010;WH,2010; Singh et al., 2011; and Khan et al., 2012). It was used to assess the knowledge of the staff nurses regarding health care waste management. It consisted of 39 items (12 items MCQ and 27 items true or false) covering nine dimensions namely: health care waste background ( 7 items), health care waste classification (5 items), health care waste hazards ( 2 items), health care waste segregation (6 items), health care waste collection (5 items), health care waste 
storage ( 3 items), health care waste transportation ( 3 items), occupational health and safety measures of health care waste management ( 3 items), universal precautions of health care waste management (5 items).

\section{Scoring System:}

The scoring system for the questionnaire sheet consisted of giving a score of (one) for the correct answer and (zero) for the wrong answer for true and false questions, while the score of knowledge of MCQ questions, giving scores of (one) for the correct answer and (zero) for the incorrect answer. The knowledge score was considered satisfactory if the score was $60 \%$ or more and unsatisfactory if it was less than $60 \%$ (Hassan, 2012).

\section{SECOND TOOL: Observation Checklist (Appendix II)}

This tool was adapted from Hassan (2012). It was used to evaluate the practice of the staff nurses regarding health care waste management. It consisted of 26 items to collect data related to the practice of nurses related to the management of wastes, which classified into eight dimensions, namely: their practice toward the segregation of hazardous waste (3), nursing trolley (6), sharps box (5), chemical waste bucket (3), small red bags (2), large red bags (2), small black bags (3), and large black bags (2).

\section{Scoring System:}

Giving a score of (one) for the step done correctly, and giving (zero) for the step not done. The practice was considered proper if the percent score was $60 \%$ or more and inadequate if less than 60\% (Samin et al., 2011).

\section{(II) OPERATIONAL DESIGN}

The operational design consists of the preparatory phase, pilot study, validity and reliability, and fieldwork.

\section{The Preparatory Phase}

It includes reviewing of literature, different studies and theoretical knowledge of various aspects of the problems using books, articles, internet, periodicals Journals. 


\section{Pilot study:}

The pilot study carried out for 2 weeks at $10 \%$ (11nurses) of the total sample to test the applicability, feasibility and clarity of the tools and to test the sequence of questions to maintain consistency. Also, served to estimate the time needed to complete the tool, according to pilot study results, minimal modifications were done and pilot included in the study.

\section{Content Validity:}

The tools were reviewed by A jury of 5 experts in Nursing administration, Community health nursing, Pediatric nursing and medical and surgical nursing from the Faculty of Nursing in Port Said, and accordingly the necessary modification was done to test their validity.

\section{Reliability:}

Reliability of the tools was checked by testing for its internal consistency using a Cronbach Alpha reliability test. Reliability was found 0.79 for knowledge questionnaire, while the observational checklist reliability was found 0.81 .

\section{Field of work:}

After obtaining necessary permissions from the hospital to carry out the study, the researcher met the medical director and matron to explain the aim and the process of the study to gain their support and cooperation. Then, the nurses were met individually, and invited to participate and obtained their consent to be recruited in the study after explaining the nature of the study and the procedure of data collection. Confidentiality and anonymity of their responses were ensured. The researcher, distributed the data collection forms with instruction about how to fill it. The filled forms were collected in time and revised to check their completeness to avoid any missing data. Each sheet took about 20-30 minutes to be answered.

The data were collected two days/week during the morning shifts. The days are Monday and Wednesday and work were done between 9:30am to 1:30pm. The researcher was present all the time to clarify any ambiguities and any questions. The field work lasted for 6 months throughout the period from March 2015 to August 2015.The observational checklist was utilized by the researcher to assess nurse's 
practice. The assessment of nurse's practice was done through three times of observation. The researcher observed each nurse for each skill for 20 minutes.

\section{(III) ADMINISTRATIVE DESIGN:}

An official permission was taken from the dean of the Faculty of Nursing in Port Said University to the nursing director of the previous mentioned hospital to ensure their cooperation and permission. Written approval was obtained to conduct the study after explaining the purpose and objectives of the study.

\section{Ethical Consideration:}

The aim of this study was explained to the nurse's director the study and their permission to participate was taken. The nurses included in the study were assured about confidentiality of the information gathered and it was used only for the purpose of the study and the nurses who were included in the study it were informed about their rights to refuse or to withdraw at any time.

\section{(IV) STATISTICAL DESIGN:}

\section{Statistical analysis:}

The raw data were coded and transformed into coding sheet. The results were checked. Then, the data were entered into SPSS system files (SPSS package version 18) using a personal computer. Output drafts were checked against the revised code data for typing and spelling mistakes. Finally, analysis and interpretation of data were conducted.

\section{RESULT:}

Table (1): shows Socio-demographic characteristics of the studied nurses. As the table shows, 110 nurses were participated in this study. $63.6 \%$ of them were in the age group $>30$ years old, with the mean of $34.3 \pm 7.8$ years. The majority of nurses (93.6\%) were female nurses. And 73.6\% had Secondary nursing diploma. More than half of them $56.4 \%$ had experienced more than five years, and all nurses attending training programs in waste management.

Table (2): clarifies total knowledge related to health care waste management as reported by the studied nurses. As the table shows that all staff nurses had knowledge 
about universal precautions and waste transportation, while $36.4 \%$ of them had knowledge about health care waste management background. Also, the majority of nurses $(80.0 \%)$ had satisfactory knowledge related to waste management.

Table (3): illustrates the total practice related to health care waste management as observed among the studied nurses. It is noticed that, all staff nurses committed to dealing with the nursing trolley, while $52.7 \%$ of observed nurses committed to dealing with the chemical waste bucket. Also the table indicated that, the majority of nurses had adequate practice.

Table (4): illustrates the relation between nurses' knowledge of health care waste management and their personal and job characteristics. As the table indicates, staff nurses who had satisfactory knowledge had age more than 30 years, were female, had a technical institute diploma, had experience in nursing field more than 10 years. Also the table revealed that there are statistically significant relations between nurse's knowledge and the nurse's age, nursing qualification, total experience and department.

Table (5): reveals the relation between staff nurses' practice level and their personal and job characteristics. As the table indicates, the highest percentage of nurses who had adequate practice had age more than 30 years, were female, had a technical institute diploma, had current experience more than 5 years and had total experience more than 10 years. Nonetheless of these relations are statistically significant.

Table (6): illustrates the relation between nurses' total knowledge of health care waste management and their total practice. As shown in this table, the highest percent of nurses who had satisfactory knowledge were had adequate practice $(86.4 \%)$. Also, there was a statistically significant relationship between total knowledge and total practice $(\mathrm{p}=0.03)$. 
Table (1): Percentage distribution of studied nurses related to Socio-demographic characteristics $(\mathrm{n}=110)$

\begin{tabular}{|c|c|c|}
\hline & No & $\%$ \\
\hline Age: & & \\
\hline$<30$ & 40 & 36.4 \\
\hline $30+$ & 70 & 63.6 \\
\hline Range & \multicolumn{2}{|c|}{$23.0-59.0$} \\
\hline Mean \pm SD & \multicolumn{2}{|c|}{$34.3 \pm 7.8$} \\
\hline Median & \multicolumn{2}{|c|}{32.0} \\
\hline \multicolumn{3}{|l|}{ Gender: } \\
\hline Male & 7 & 6.4 \\
\hline Female & 103 & 93.6 \\
\hline \multicolumn{3}{|l|}{ Nursing qualification: } \\
\hline Secondary nursing diploma & 81 & 73.6 \\
\hline Technical institute diploma & 29 & 26.4 \\
\hline \multicolumn{3}{|l|}{ Experience years (total): } \\
\hline$<10$ & 31 & 28.2 \\
\hline $10+$ & 79 & 71.8 \\
\hline Range & \multicolumn{2}{|c|}{$2.0-39.0$} \\
\hline Mean \pm SD & \multicolumn{2}{|c|}{$15.2 \pm 8.1$} \\
\hline Median & \multicolumn{2}{|c|}{13.5} \\
\hline \multicolumn{3}{|l|}{ Experience years (current): } \\
\hline$<5$ & 48 & 43.6 \\
\hline $5+$ & 62 & 56.4 \\
\hline Range & \multicolumn{2}{|c|}{$1.0-6.0$} \\
\hline Mean \pm SD & \multicolumn{2}{|c|}{$4.6 \pm 1.6$} \\
\hline Median & \multicolumn{2}{|c|}{5.0} \\
\hline \multicolumn{3}{|l|}{ Department: } \\
\hline Emergency & 25 & 22.7 \\
\hline $\mathrm{CCU}$ & 11 & 10.0 \\
\hline Critical care & 16 & 14.5 \\
\hline Outpatient & 9 & 8.2 \\
\hline Central sterilization & 6 & 5.5 \\
\hline Operation room & 14 & 12.7 \\
\hline Medical & 16 & 14.5 \\
\hline Surgical & 13 & 11.8 \\
\hline \multicolumn{3}{|l|}{$\begin{array}{l}\text { Attending training program in waste } \\
\text { management: }\end{array}$} \\
\hline Yes & 110 & 100 \\
\hline No & 0.0 & 0.0 \\
\hline
\end{tabular}


Table (2): Percentage distribution of studied nurses knowledge related to health care waste management $(\mathrm{n}=110)$

\begin{tabular}{||l|c|c||}
\hline \multicolumn{1}{|c|}{ Satisfactory knowledge (60\%+) of: } & \multicolumn{2}{|c||}{ No } \\
\hline Waste management elements knowledge: & 40 & 36.4 \\
Background of waste management & 74 & 67.3 \\
Waste classification & 80 & 72.7 \\
Waste hazards & 89 & 80.9 \\
Waste segregation & 109 & 99.1 \\
Waste collection & 88 & 80.0 \\
Waste storage & 110 & 100.0 \\
Waste transportation & 70 & 63.6 \\
Occupational safety measures & 110 & 100.0 \\
Universal precautions & & \\
Total knowledge: & 88 & 80.0 \\
\hline Satisfactory & 22 & 20.0 \\
\hline Unsatisfactory & & \\
\hline
\end{tabular}

Table (3): Percentage distribution of studied nurses practice related to health care waste management $(\mathrm{n}=110)$

\begin{tabular}{||l|c|c||}
\hline \multicolumn{1}{|c|}{$\begin{array}{c}\text { Waste management practice area: } \\
\text { Adequate practice }(\mathbf{8 0} \%+) \text { of: }\end{array}$} & \multicolumn{2}{c|}{ Practice percent } \\
\cline { 2 - 3 } Segregation of hazardous waste & No & $\%$ \\
Nursing trolley & 110 & 100.0 \\
Sharps box & 85 & 77.3 \\
Chemical waste bucket & 58 & 52.7 \\
Small red bags & 68 & 61.8 \\
Large red bags & 109 & 99.1 \\
Small black bags & 67 & 60.9 \\
Large black bags & 108 & 98.2 \\
Total practice: & & \\
Adequate & 90 & 81.8 \\
Inadequate & 20 & 18.2 \\
\hline \hline
\end{tabular}


Table (4): Relation between nurses' knowledge of health care waste management and their socio-demographic characteristics $(n=110)$

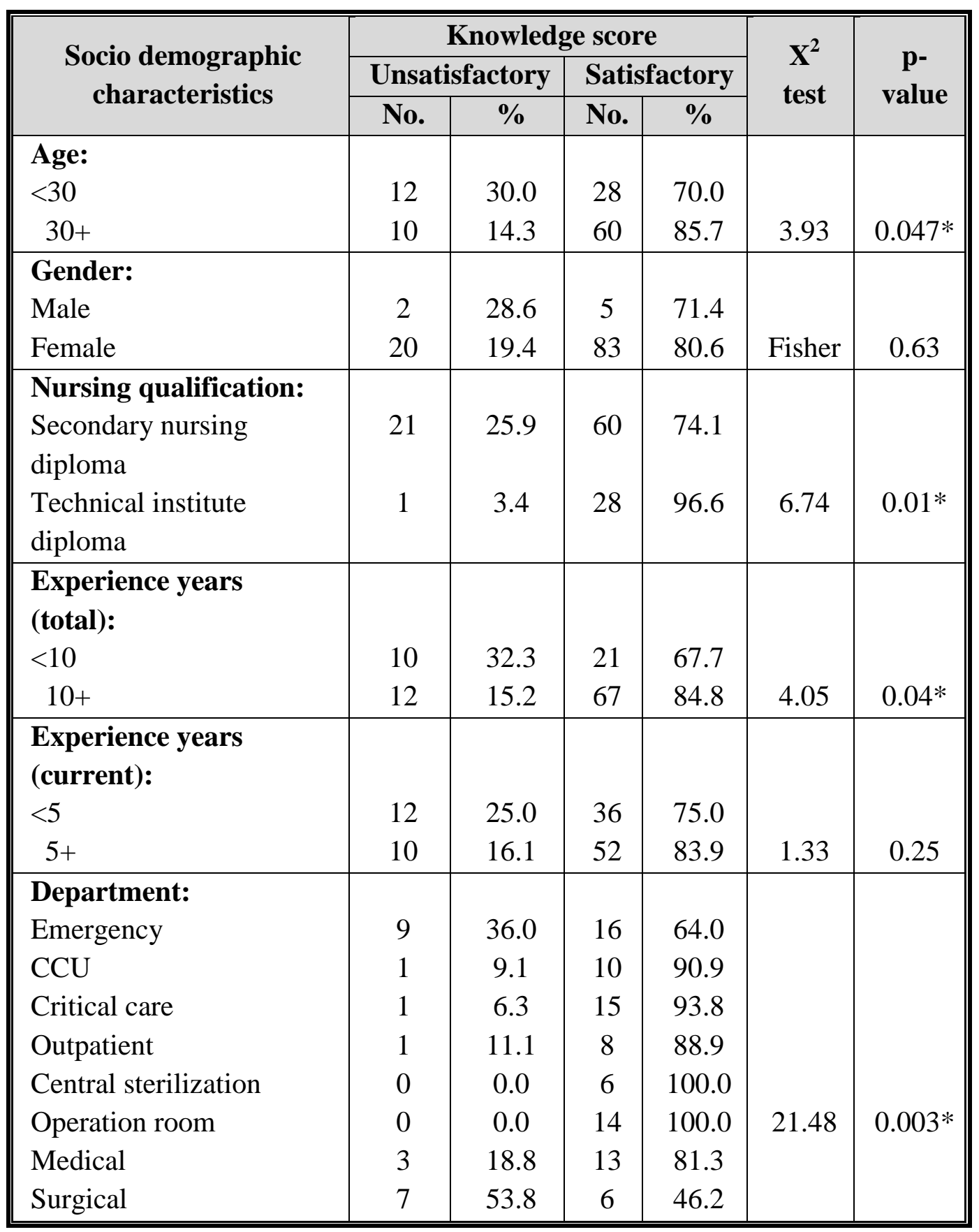

(*) Statistically significant at $p<0.05$ 
Table (5): Relation between nurses' practice of health care waste management and their socio-demographic characteristics $(n=110)$

\begin{tabular}{|c|c|c|c|c|c|c|}
\hline \multirow{3}{*}{$\begin{array}{c}\text { Socio demographic } \\
\text { characteristics }\end{array}$} & \multicolumn{4}{|c|}{ Practice score } & \multirow{3}{*}{$\begin{array}{c}\mathrm{X}^{2} \\
\text { test }\end{array}$} & \multirow{3}{*}{$\begin{array}{c}\text { p- } \\
\text { value }\end{array}$} \\
\hline & \multicolumn{2}{|c|}{ Adequate } & \multicolumn{2}{|c|}{ Inadequate } & & \\
\hline & No. & $\%$ & No. & $\%$ & & \\
\hline \multicolumn{7}{|l|}{ Age: } \\
\hline$<30$ & 31 & 77.5 & 9 & 22.5 & \multirow{2}{*}{0.79} & \multirow[b]{2}{*}{0.37} \\
\hline $30+$ & 59 & 84.3 & 11 & 15.7 & & \\
\hline \multicolumn{7}{|l|}{ Gender: } \\
\hline Male & 5 & 71.4 & 2 & 28.6 & \multirow[b]{2}{*}{ Fisher } & \multirow[b]{2}{*}{0.61} \\
\hline Female & 85 & 82.5 & 18 & 17.5 & & \\
\hline \multicolumn{7}{|l|}{ Nursing qualification: } \\
\hline Secondary nursing diploma & 65 & 80.2 & 16 & 19.8 & \multirow[b]{2}{*}{0.51} & \multirow[b]{2}{*}{0.48} \\
\hline Technical institute diploma & 25 & 86.2 & 4 & 13.8 & & \\
\hline \multicolumn{7}{|l|}{ Experience years (total): } \\
\hline$<10$ & 22 & 71.0 & 9 & 29.0 & \multirow[b]{2}{*}{3.42} & \multirow[b]{2}{*}{0.06} \\
\hline $10+$ & 68 & 86.1 & 11 & 13.9 & & \\
\hline \multicolumn{7}{|l|}{ Experience years (current): } \\
\hline$<5$ & 39 & 81.3 & 9 & 18.8 & \multirow[b]{2}{*}{0.02} & \multirow[b]{2}{*}{0.89} \\
\hline $5+$ & 51 & 82.3 & 11 & 17.7 & & \\
\hline \multicolumn{7}{|l|}{ Department: } \\
\hline Emergency & 10 & 40.0 & 15 & 60.0 & \multirow{8}{*}{--} & \multirow{8}{*}{--} \\
\hline $\mathrm{CCU}$ & 9 & 81.8 & 2 & 18.2 & & \\
\hline Critical care & 16 & 100.0 & 0 & 0.0 & & \\
\hline Outpatient & 9 & 100.0 & 0 & 0.0 & & \\
\hline Central sterilization & 5 & 83.3 & 1 & 16.7 & & \\
\hline Operation room & 14 & 100.0 & 0 & 0.0 & & \\
\hline Medical & 16 & 100.0 & 0 & 0.0 & & \\
\hline Surgical & 11 & 84.6 & 2 & 15.4 & & \\
\hline
\end{tabular}

(--) Test result not valid 
Table (6): Relation between nurses' total knowledge of health care waste management and their total practice $(n=110)$

\begin{tabular}{|c|c|c|c|c|c|c|}
\hline \multirow{3}{*}{ Total knowledge } & \multicolumn{4}{|c|}{ Total practice } & \multirow{3}{*}{$\begin{array}{l}X^{2} \\
\text { test }\end{array}$} & \multirow{3}{*}{$\begin{array}{c}\text { p- } \\
\text { value }\end{array}$} \\
\hline & \multicolumn{2}{|c|}{ Adequate } & \multicolumn{2}{|c|}{ Inadequate } & & \\
\hline & No. & $\%$ & No. & $\%$ & & \\
\hline \multicolumn{7}{|l|}{ Total knowledge: } \\
\hline Unsatisfactory & 14 & 63.6 & 8 & 36.4 & & \\
\hline Satisfactory & 76 & 86.4 & 12 & 13.6 & Fisher & $0.03 *$ \\
\hline
\end{tabular}

(*) Statistically significant at $\mathbf{p}<0.05$

\section{DISCUSSION:-}

In the $21^{\text {st }}$ century, medical waste management has become a critical issue in health care organizations. As it poses potential environment hazards and public health risks with high propensity to result into the epidemic, especially in developing countries (Awodele, Adewoye \& Opar 2016).

In this context, the result of the present study revealed that most nurses were females, had more than 30 years old, and ranged from 23-59 years old with a mean of 34.1 \pm 7.8 . The majority of them had a secondary nursing diploma, and had experience in nursing field more than ten years. And all of them were attending training programs in waste management.

Regarding staff nurses' knowledge level, the result of the present study showed that the majority of nurses had satisfactory knowledge regarding health care waste management. This may be attributed to the supervision of infection control nurse, refresher conferences during employment, availability of waste management handouts to be used as a nursing guide, an orientation program related to waste management \& training facilities. This interpretation is supported by Wasee, Hassan, Baba, Kadrizo \& Nazi (2010) who reported that the better knowledge of the nurses could be attributed to the fact that they are being more involvement of nurses in hospital waste management by appointing infection control nurse who was responsible for BMW 
policy formation, implementation and revision, and periodic in-service education programs being conducted, almost on monthly basis.

Similar findings were reported by Saini, Nagarajan \& Sarma (2011) who evaluated the biomedical waste management among staff nurses of a tertiary level hospital in India, showed that $85 \%$ nurses had good knowledge about biomedical waste management. Also, in a study to evaluate the knowledge, attitude \& practice of the health care team regarding biomedical waste management methods by Awodele et al. (2016) found that $95.8 \%$ of nurses had knowledge about the health hazards of biomedical waste management.

In the same line, Ramokate et al. (2013) who study knowledge, attitude and practices regarding biomedical waste management among nursing staff in private hospitals in India and reported that, the majority of nursing staff had perception regarding BMW that it is different from general wastes and require special attention for its proper management. This is consistent with the findings of a study done among doctors and nurses on knowledge and practices regarding biomedical waste management at Johannesburg, which showed that $90 \%$ of respondents treated biomedical wastes differently than general wastes (Sawalem\& Selic, 2012).

While these findings were contrasted with that of Mustafa, Shazly \& Sherief (2012) who found that that almost all nurses (98.7\%) had unsatisfactory knowledge regarding health care waste management before the implementation of the educational training program at Mansoura university Hospital. Also, the result of the present study is inconsistent with $\boldsymbol{E L}$-Awady, (2009) who implemented an educational program about medical waste management in Zagazig university hospitals and found that minority (25\%) of participants have good knowledge. On the same line, Deno (2011) who found that, the mean knowledge score of nurses who working in a general hospital in Malaysia was $45.5 \pm 10.52$, which reflect unsatisfactory knowledge. 
Concerning the nurses' practice level, the findings of the present study revealed that the majority $(81.8 \%)$ of nurses had adequate practices in most areas of waste management. These findings could be explained by the fact of satisfactory knowledge of staff nurses in the present study, presence of training courses and programs, the availability of adequate supplies and good supervision of the infection control team, and nurses think biomedical waste management as an important prerequisite for a good patient care service. This interpretation was supported by Mathur et al. (2011) who stated that good practice is the result of theoretical understanding that helps nurses to acquire new skills. This result congruent with Shafee et al. (2010) who claimed that all nurses were practicing health care waste according to the rules.

This is consistent with the findings of a study done among the nurses on knowledge and practices regarding biomedical waste management at Johannesburg, which showed that $90 \%$ of respondents treated biomedical wastes differently than general wastes (Awodele et al., 2016). In contradiction with Mustafa et al. (2012) who assessed the knowledge \& practice related to waste management among health care workers (doctors, nurses \& housekeepers) at the AL Mansoura university hospital and proved that inadequate nursing practice in most areas of waste management. Also, Emmanuel (2007) found that all nurses had inadequate practice regarding health care waste management. Meanwhile, Khan (2014) stated that less than half $(45.4 \%)$ of nurses are practicing/following biomedical waste management rules.

Regarding the relation between staff nurses' knowledge level and personal characteristics; the study findings revealed that, there was a positive relation between nurse's knowledge and their age \& years of experience. This means that with an increase in age and experience there is a significant increase in knowledge regarding BMW. This may be due to that older nurses were adjusted to the hospital system and routine work and attendance many educational programs. Also, nurses with more years of nursing experience become more expert and knowledgeable.

This is the same view of Patil \& Shekdar (2004) who proved that nurses with more years of nursing experience become more expert, knowledgeable, and they had 
more confidence to pursue a standard of excellence. These findings are congruent with Ismail et al. (2013) who concluded that with an increase in age and experience there is significant increases in knowledge regarding BMW among nursing staff in INDIA.

This is in contrast with Al-Khatib (2007) who showed that years of experience had no influence on knowledge of the staff nurse's regarding health care waste. He thought that this could be due to lack of regular system of in service orientation courses about recent scientific information. Moreover, Saraf \& Shinda, (2009) proved that a negative relation between personal characteristics and nurses' knowledge.

Regarding the relation between staff nurses' practice level and personal characteristics; the study findings revealed that, there was a positive statistically significant relation between nurse's practice and their age $\&$ years of experience. This means that with an increase in age and experience there is a significant increase in practice regarding BMW. This may be due to that older and more experience nurses were attending many training programs. This view was supported by Radha (2012) who found that training of both the technical staff and the non-technical staff is critical for the proper and appropriate management of biomedical waste.

Additionally, this finding agreed with Mohamed (2009); Mnowan (2012) who reported that there was a positive statistically significant relationship between nurses' age and their performance. Hence, the older nurse value knowledge and practice acquired nurses from their experience more highly than the knowledge and practice gained from formal education. This finding was on the contrary, with Hassan (2012); Katoch (2007) who found that there was no statistical significant relation between nurse's practice and their years of experience.

Concerning the relationship between knowledge and practice among staff nurses; the findings indicated a statistically significant correlation between nurse knowledge and practice scores of staff nurses. This is may be attributed to that hospital subservient to qualify of quality and the hospital has already been on the receiving the foundation level and the nurses who had adequate knowledge attended waste 
management training program and they were more committed to practice waste management policy and rules than other nurses. In this context, WHO (2005) stressed the overall aim of training is both to create a competent workforce and develop awareness of the health, safety and environmental issues relating to the healthcare waste management, and how these can affect nurses in their daily work.

As well, Khan et al. (2012) found that a statistically significant correlation between nurse knowledge and practice scores. Also, Hassan (2012) who reported that there was a significant positive correlation between nurses' knowledge and performance. Moreover, Sarma et al. (2011) who found that the nurses with good knowledge had very high practice percentage

\section{CONCLUSION:-}

Based on the study findings, it can be concluded that $80 \%$ of staff nurses had satisfactory knowledge regarding health care waste management, and $81.8 \%$ of staff nurses had adequate practices in most areas of waste management. Also, it can be concluded that there was a statistically significant correlation between nurses' knowledge and practice related to health care waste management in El-Zohor hospital. And there was a positive, statistically significant relation between nurses' knowledge, practice and their social demographic characteristics in terms of age \& years of experience.

\section{RECOMMENDATIONS}

Based on the findings of the present study the following recommendations were deduced:

\section{In hospital management}

1. The hospital should develop clear plans and policies for proper management and disposal of hospital wastes. Safe hospital waste management policies and guidelines should be activated and available in all hospital departments.

2. Allocate sufficient financial and manpower resources for the implementation of HCWM plan. 
3. There should be close monitoring and supervision to ensure the application of safety regulations in waste handling and to develop effective implementation of HCWM in hospitals.

4. Motivating the staff nurses through the application of specific rewards schemes for safe waste management practices.

\section{In education}

1. Continuous assessment of nurses' knowledge and practice toward waste management in hospital is essential to identify nurses training needs.

2. Proper training is necessary to develop an awareness of health, safety and environmental issues. It is important for staff to know and understand the potential risks associated with health care wastes.

3. There is a need to educate the staff nurses about the hazards of needle stick injuries through a well-organized infection control program, spreading awareness and education of infection control measures, disease transmissions, post exposure prophylaxis and on benefits of vaccines and other preventive ways so that a change in attitude can be successfully achieved.

4. The hospital should provide staff nurses with in-service training program in the management, practice and monitoring of healthcare waste.

\section{In research}

Further studies need to be conduct to:

1. Assess nurse's knowledge and practice regarding biomedical waste management, factors and barriers that affect it.

2. Re-evaluate the relationship between knowledge and practice.

\section{REFERENCE :-}

Al-Khatib I.A. (2007): Assessment of medical waste management in a Palestinian hospital]. Eastern Mediterranean Health Journal, 12(2), pp.359-371 [in Arabic].

Athy, L.R. (2009): Biomedical Waste Management-Regulatory Compliance and Management of BMW Facilities. Available at http://www.basel.int/natreporting/cfs/.doc.

Aukour FJ. (2008): Health-care Waste Management in Jordan King Abdullah University Hospital Case Study. J. Sci. Med. Eng., 20(1), pp. 61-77. 
Awodele, O., Adewoye, A. and Oparah, A: (2016). Assessment of medical waste management in seven hospitals in Lagos, Nigeria. BMC public health, 269, DOI: 10.1186/s12889-016-2916-1. http:// www.biomedcentral.com/content/pdf/s12889-0162916-1.pdf

Deno, T. (2011): Medical Waste Management Education and Training. Available at http://www.business.com.

El-Awady, S.M. (2009): Compliance Universal Precaution among nurses and laboratory technician in Mansoura international specialized hospital. Unpublished master thesis. Faculty of Nursing, Zagazig University, Egypt. Pp.82-94.

Emmanuel J. (2007): Best environmental practices and alternative technologies for medical waste management. Paper presented at the Eighth International Waste Management Congress and Exhibition. Institute of Waste Management, Botswana, South Africa, 25-28 June.

Fasola GM., Aita L., Marin A., Follador M., Tosolini L., Mattioni M., Mansutti A., Piga S., Brusaferro and Aprile G. (2008): Drug Waste Minimization and CostContainment in Medical Oncology: Two-year results of a feasibility study. BMC Health Serve Research, 1(8), pp. 70-74.

Fluke, C. (2000): Handling hazardous waste. Journal Health Mater Management, 12 (6), pp. $70-73$.

Goddu VKK, Duvvuri and Bakki VK. (2007): A critical Analysis of Healthcare Waste Management in Developed and Developing Countries: Case studies from India and England. Proceedings of the international Conference on Sustainable Solid Waste Management. Chennai, India, 5(7), pp. 134-141.

Hassan S. (2012): Assessment of management of health care waste in selected obstetric and gynecological department at el-manial university hospital, faculty of nursing, Cairo University, pp.69-82. 
Hedge, V., R.D. Kulkarni and G.S. Ajantha, (2009): Biomedical Waste Management. Journal of Oral and Maxilla Facial Pathology, 11(1), pp. 5-9.

Ismail, I.M., Annarao, G., Kulkarnietal. (2013): Knowledge, attitude and practice about bio-medical waste management among personnel of a tertiary health care institute in Dakshina Kannada, Karnataka. Al-Ameen J Mical Sciences 2013, 6(4), pp.376-80.

Khan N., Khowaja KZA. and Ali TS (2012): Assessment of knowledge, skill and attitude of nurses in chemotherapy administration in tertiary hospital Pakistan. Open $\mathbf{J}$ Nursing, 2(3), pp. 97-103.

Khan JA. (2014): Hospital waste management issues and steps taken by the Government of Pakistan. Islamabad, Pakistan, Ministry of Environment. Retrieved at 2 May 2012 from: sskatoch@nitham.ac.in

Katoch, S. (2007): Biomedical waste classification and prevailing management strategies, proceedings of the international conference on sustainable solid waste management, Civil Engineering Department, National Institute of Technology, Hamirpur (HP), Chennai, India,Pp.169-175.

Mathur, V., Dwivedi, S., Hassan, M.A., Misra, R.P. (2011): Knowledge, attitude, and practices about biomedical waste management among health care personnel: acrosssectional study. Indian J Community Med, 3(6), pp.143-155.

Mnowan, V. (2012): Awareness and management of hospital waste in developing countries: a case study in Thailand, the Faculty of The School of Engineering and Applied Science of The George Washington University, Pp.8-21.

Mohamed, A.M. (2009): Assessment of Nurses Performance Related to Nosocomial Infection Prevention in Kidney Dialysis Unit at Damietta city. Master thesis in community health nursing. Faculty of Nursing. Zagazig University, Egypt, Pp, 89-102. 
Mustafa, G., Shazly, M. and Sherief, W. (2012): Development of a waste management protocol based on assessment of knowledge and practice of healthcare personnel in surgical departments. Waste Management; 29 (1), pp. 430-439.

Onursal, B. (2011): Health care waste management. Lessons from Experience, India, the World Bank. pp. 18-22.

Pasupathi P., Sindhu S., Ponnusha SH. and Ambika A. (2011).: Health care waste management for health-care industry. Department of clinical Biochemistry and Department of Microbiology, Institute of Laboratory Medicine, KG Hospital and Post Graduate Medical Institute, Coimbatore, Tamil Nadu, India. International Journal of Biological and Medical Research, 2 (1), pp. 472-486.

Patil, A.D. and Shekdar, A.V. (2004): Health-care waste management in India. J Environ Manage, 6(3), pp.211-219. [PubMed]

Patil, G.V. and K. Pokhrel, (2012): Biomedical Solid Waste Management in an Indian Hospital: A case study. Waste Management, 25(6), pp. 592-599.

Radha R. (2012): Assessment of existing knowledge, attitude and practice regarding biomedical waste management among the health care workers in tertiary care rural hospital. International journal of health sciences and research, 2(7), pp.14-19.

Rao PH. (2008): Hospital Waste Management Awareness and Practices: A study of Three States in India. Waste Management Res, 26(9), pp. 297-303.

Ramokate, T. and Basu, D. (2013): Health care waste management at an academic hospital: knowledge and practices of doctors and nurse. South African Medical Journal, 99(6), pp.444-450.

Saini, S., Nagarajan, S.S. Sarma, R.K. (2011): KAP of BMW Management amongst staff of a tertiary level hospital in India. JA cad Hosp Admin, 17(1), pp.1-12. 
Samin H, Khezri S, Erfani Z and Amraji L A. (2011): Waste Minimization in Hospitals (Case Study: Shahid Akbar Abadi Hospital) Islamic Azad University, Tehran, Iran. http://www.who.int/water_sanitation_health/medicalwaste/wastemanag/en.

Saraf, Y. and Shinde. M. (2009): Study of Awareness status about Hospital Waste Management among Personnel Community Medicine, and Quantification, Indian Journal of April-June, 31(2),pp.11.

Sarma, R.K., Nagarajan,S.S. and Saini S. (2011): Facilities-Waste Attitudes and Actions. Available at: http://www.asianhhm.com/ facilities_operations/attitudes_actions.htm.

Sawalem, M.and Selic, E. (2012): Hospital waste management in Lybia: A case study. Waste Management journal, 29 (6), pp. 1370-1375.

Shafee, M., Kasturvar, N.B., Nirupama, N. (2010): Knowledge, attitude an practices regarding biomedical waste among paramedical workers; and rapradesh, Karimnagar, India. Indian J Community Med, 35(6), pp.369-70.

Singh, E., Ritu, T., Kishore, R., Jugal, G., Mathur R., Mandal, K., Puri, W., and Sushil, H. (2011): Role of an information booklet on bio-medical waste Management for nurses, The Nursing Journal of India. Retrieved at 14 March 2012. From: http://findarticles.com/p/articles/mi_qa4036/is_200212/ai_n9149183/.

Soliman, S.M. and A.I. Ahmed, (2010). Overview of Biomedical Waste Management in Selected Governorates in HealthCare Wastes: Generation, handling, treatment and disposal, Brief Description of the Sector Small-scale. Part II Chapter 8. Africa. pp. 3-15. Retrieved at 11 July 2012 from: www.encapafrica.org/egssaa/medwaste.pdf.

Sreegiri S. and Babu GK. (2009): Health care Waste Management in a Tertiary Level Hospital in Visakhapatnam. J. Community Medicine, 5(2), pp. 1-6. 
Wasee, Q., Hassan, G., Baba, A., Kadri, S.M. and Nazi, K. (2010): Awareness of biomedical waste management amongst staff of the government SMHS hospital, Srinagar a Tertiary level hospital in Kashmir valley. JK-Practitioner; 14(1), pp.60-66.

World Health Organization, (WHO). (2005): Management of solid healthcare wastes at primary Healthcare centers. Decision making guide, WHO Document Production Services. Pp.13-18

\section{معلومات وممارسات هيئة التمريض تجاة الرعاية الصحية لادارة المخلفات داليا رضا أحمد صبح، سماح فيصل فخرى، هند عبدالله محمد معيده - كلبة التصريض- جامعة قناة السوبي، أستاذ مساعد إدارة التمريض- كلية التصريض- جامعة عبن شمس، مدرس إدارة التصريض- كلبة التمريض - جامعة بورسعيد}

\section{الخلاصة}

الرعاية الصحية لادارة المخلفات لها أهية كبيرة نظرا للمخاطرة البيئية المحتملة ومخاطر ها علي الصحة العامة. الإدارة الآمنة لنفايات الرعاية الصحية يمكن أن تتحقق من خلال ضمان المعالجة الآمنة للنفايات عن طريق الفريق الصحي. ولذا فإن إدارة المستشفيات و مقدمي الرعاية الصحية وخاصة الممرضات تتحمل المسئولية في هذا الأمر.

وقد هدفت الدر اسة الحالية إلي تقييم معلومات و ممارسات هيئة التمريض تجاة الرعاية الصحية لادارة المخلفات بمستشفي الزهور، وقد إستخدمت دراسة وصفية وكانت عينة البحث (110) ممرضة، وتم جمع البيانات بإستخدام آدنان و هما: إستبيان لتقييم معلومات التمريض و إستمارة لملاحظة ممارسات التمريض، وتنثير النتائج إلي أن الغالبية العظمي من الممرضات كانو علي دراية مرضية بشان إدارة نفايات الرعاية الصحية و أيضا ممارسات كافية في معظم مجالات إدارة النفايات. و نستخلص من الدراسة أن هنالك علاقة إيجابية ذات دلالة إحصائية بين معلومات و ممارسات تجاة الرعاية الصحية لادارة المخلفات. لذلك نوصي بضرورة تقديم برامج التدريب و التعليم المستمر عن إدارة النفايات للمرضات بالإضافة إلي الرصد الدقيق لضمان تطبيق لو ائح السلامة للتعامل مع النفايات بشكل آمن مستمر. 